\title{
ETHNOBOTANICAL USE OF LICHENS: LICHENS FOR FOOD REVIEW
}

\author{
Ivanova D., D. Ivanov* \\ Department of Biochemistry, Molecular Medicine and Nutrigenomics, *Department of Pharmacy, \\ Medical University "Prof. Dr. Paraskev Stoyanov" - Varna
}

Reviewed by: Assoc. Prof. T. Yankova

\begin{abstract}
Traditional uses of lichens for food, food preparation, and chemical constituents of lichens with regards to their nutritional value are briefly reviewed. Reports that indicate significant use of lichens, primarily as food material, are gathered together and presented. The cohesion of data from available studies gives reason to accept that lichens present a great potential source of functional foods. It remains a challenge to explore the effect of lichens in food with respect to the nutrigenomics advent and explore them as a source for nutraceuticals, new foods and food additives.
\end{abstract}

Key words: lichens, food, nutritional value, ethnobotanical use

\section{INTRODUCTION}

"Lichens are the most overlooked of the conspicuous organisms in the natural landscape. The eye often cannot see what the mind does not already know." Sylvia Sharnoff Most data about ethnobotanical use of lichens originate from legends across the whole world, few have been recorded by travelers, and many are being lost with the advances of civilization. The unique biochemical compounds produced by lichens have made them useful to people in traditional cultures as food, source for dyes, fragrances and medicines.

Lichens grow in all continents and the lichen flora varies upon the climate and relief. It is estimated that lichens are the dominant vegetation on $8 \%$ of the earth's terrestrial surface. Thus lichens are a part of many food webs which include humans, vertebrates, and invertebrates. There are records of lichens being used as food by many different human cultures for millennia, 107 peoples have used lichens in North America alone. Lichens are eaten by people in America, Europe, Asia, and Africa, and perhaps elsewhere $(23,29,30,40)$. A century ago it had been prophesized that lichens were to become the great popular food of the masses, because of their cheapness and nutritive properties (36). This did not happen, but lichens had frequently been used as famine food by people. And there are also many peoples who have used lichens for food on a more regular basis, even as a delicacy (like Umbilicaria esculenta

Address for correspondence:

D. Ivanova, Dept. Biochemistry, Molecular Medicine and Nutrigenomics, Prof. P. Stoyanov Varna University of Medicine, 55 Marin Drinov Str., BG-9002, Varna, Bulgaria

e-mail: divanova@mu-varna.bg
(Miyoshi) Minks. in Japan) or a dessert (like Cetraria islandica (L.) Ach. in Scandinavia and France).

Even though that some lichens are thought to be among the oldest living organisms on Earth, as a general they are less familiar than vascular plants, and are frequently grouped with other fungi or with mosses in many studies. Nomenclature is often vague, particularly in the older literature. In the northern regions, and in higher elevation habitats, where lichen use seems to be heaviest in winter, fewer studies have been done. For those reasons scientists in their search for new functional foods, nutraceuticals and food additives are prone to ignore lichens due to their size, slow growth, and very insufficient knowledge on their composition and biological properties of their constituents.

\section{Nutritional value of lichens}

There are two major problems that people have generally encountered when eating lichens. These are secondary lichen compounds, many of which are acids and thus have an acrid flavor, and complex carbohydrates, that are difficult to digest and are irritating to the digestive tract.

Lichens produce a wide array of both primary (intracellular) and secondary (extracellular) compounds. Primary metabolites include amino acids, polyols, carotenoids, polysaccharides, and vitamins. Secondary metabolites are often called lichen acids - produced primarily by the mycobiont, they are deposited externally on the hyphae of the cortex and/or medulla. Lichen acids are derived from three chemical pathways: shikimic acid pathway, a source of pulvinic acid derivatives (yellow pigments), mevalonic acid pathway (a source of terpenes), and acetate-polymalonate pathway, in which the majority of lichen compounds are produced (depsides, depsidones, usnic acid, anthraquinones, xanthones, aliphatic acids). Common 
products of the mevalonic acid pathway include steroids and triterpenes like zeorin (found in many Cladonia taxa). Acetate-polymalonate pathway includes the most common lichen compounds: derivatives of orcinolor $\beta$-orcinolunits, depsides, depsidones, depsones, anthraquinones (most are red-purple pigments in the cortex or apothecia), xanthones (fluorescent), as well as aliphatic fatty acids. Usnic acid (an extremely common yellow-green cortical pigment) is one of the medically useful lichen acids.

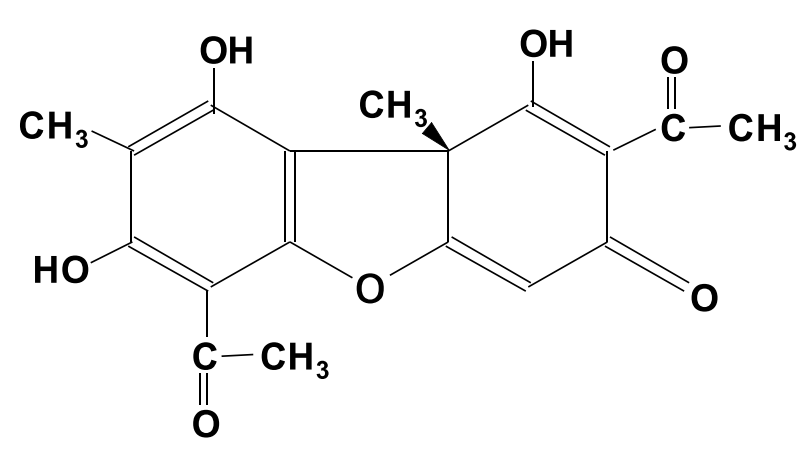

Fig. 1. Usnic acid

Few lichen compounds have been found to be poisonous, such as usnic (Fig. 1) and vulpinic (Fig. 2) acids, and if these compounds would have to be ingested in significant amounts, they could be fatal for humans. Usnic acid is a prominent secondary lichen metabolite that has been used for various purposes worldwide. Crude extracts of usnic acid or pure usnic acid have been marketed in the United States as dietary supplements to aid in weight loss. The US Food and Drug Administration (FDA) received numerous reports of liver toxicity related to the ingestion of dietary supplements that contain usnic acid (13). Besides those, many other lichen compounds are herbivore deterrents, and can be very bad tasting, a digestive irritant, and would probably even be toxic if eaten in large quantities for extended periods of time.

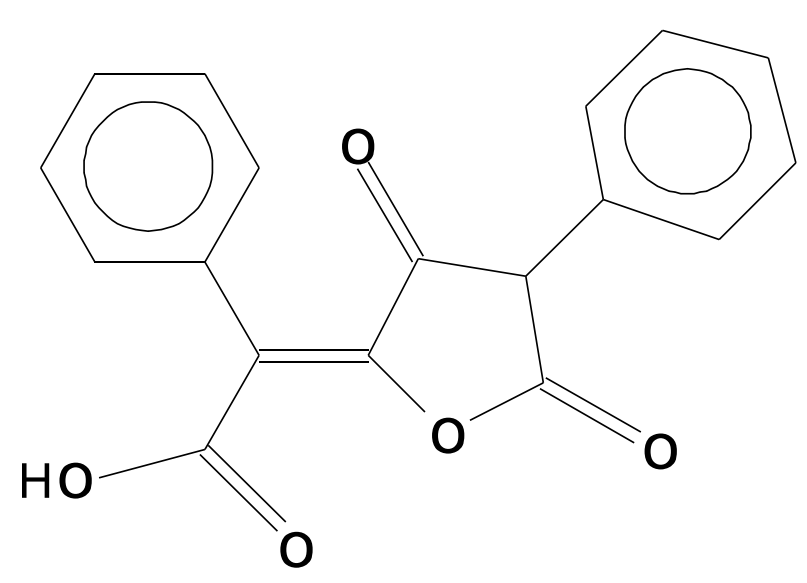

Fig. 2. Vulpinic acid

The second problem with eating lichens is that the complex carbohydrates in lichens are not easily broken down in the human digestive tract (18). Several types of lichens that were eaten in different parts of the world $(22,28)$ were usually treated prior consumption to remove some of the toxic compounds or to break lichen polysaccharides into simple sugars that could be absorbed by human intestinal mucosa. Some lichens were even collected partially digested from caribou rumens (reindeer lichen, Cladonia spp.). Lichens contain a variety of polysaccharides - evernin, usnin (36), cellulose and inulin (22),lichenin (soluble in hot water, a-(1-3)(1-4)-D-glucan), isolichenin (soluble in cold water, $\beta-(1-3)(1-4)-D-$ glucan). Crude fiber in the lichens contains a significant amount of lichenin and isolichenin, carbohydrates that are digestible by ruminants. After lichenin and isolichenin are hydrolyzed in the rumen digestive tract, they yield glucose and other readily digestible simple sugars. In addition, a high fiber content of Cladonia spp. broken down by rumen bacteria and protozoa may liberate large amounts of energy which would be advantageous to ruminants living under extreme winter conditions (33). Lichen carbohydrates were fairly well studied over a century ago, after Külz suggested in 1874 that they could be eaten as substitute carbohydrates by diabetics (36).

People have traditionally used various preparation methods to make lichens edible by removing the lichen secondary compounds and hydrolyzing the lichen polysaccharides. The most frequently used preparation technique is boiling or steaming, used in North America, Europe, and India. Boiling would help to hydrolyze the lichen polysaccharides into digestible forms. It is recorded that people would often boil the lichen and afterwards discard the water to remove lichen compounds. The lichens were also often soaked or rinsed with water. Sometimes North Europeans and North American natives used ash water to soak the lichens. As wood ash is alkaline, it could have been more effective in removing the acidic lichen compounds or help to hydrolyze lichen polysaccharides. Addition of diluted acids, or acidic ingredients like onion, was common when cooking lichens. Acids could also have helped to hydrolyze lichen polysaccharides, or increase solubility of certain lichen compounds.

Lichens may also provide some other nutrients to the diet. Lal and Rao (1956) found calcium and iron levels to be higher in some lichens than in cereals and thus comparable to green leafy materials (19). The calcium to phosphorus ratio they found was from 2 to 14 , and they considered that lichens could serve as a good source of calcium.

Lichens are generally regarded as low in protein but this is true for the species most sought after by caribou and deer. The fruticose Cladonia, and Cetraria genera, and the arboreal Alectoria, Bryoria, and Usnea, all of which are the favoured forage of caribou, contain a rough average of $2 \%$ crude protein. However, some of the foliose lichens, such as Peltigera spp. and Lobaria spp. have much more protein (33). Several species of Peltigera had a fairly high content of crude protein (from $17 \%$ to $21 \%$ ), and Peltigera canina (L.) Willd. has been found to be relatively high in essential amino acids. In addition, the digestibility of lichen protein may be low - results of Swedish experiments, reported by Nordfeldt et al. (1961), indicated low lichen proteins digestibility (25). 
Various studies have shown lichens to contain some vitamins, but results have not been consistent. Lichens which were the principal food for reindeer in winter contained little carotene. Cladonia arbuscula (Wallr.) Flot. and Cladonia rangiferina (L.) F.H.Wigg., important winter feeds for reindeer and caribou, contained vitamin $\mathrm{D}$ and it was speculated that they represented a vital source of vitamin D for the animals, especially during winter (39).

Scarce data indicate a relatively high antioxidant content of lichen extracts $(4,12,14)$, generally with regards to their usage as remedies in folk medicines. On the other hand, research on antioxidant properties of lichens is mainly focused on lichen adaptation to the environment $(7,41)$.

One disadvantage of eating lichens, particularly for humans, is that lichens can accumulate toxins from their environment. Cetraria islandica (L.) Ach. and Cladonia spp. have been found to contain particularly high levels of lead, cadmium, and mercury, and Parmelia saxatilis (L.) Ach. and Xanthoria parietina (L.) Th.Fr. have been found to absorb enough beryllium from their environment to become harmful to animals (22). Xanthoparmelia conspersa (Ach.) Hale can accumulate toxic levels of selenium salt (22). Moreover, lichens absorb and accumulate radioactive fallout far more than vascular plants and pass it along in the food chain. The natural radionuclides $\mathrm{Po}^{210}$ and $\mathrm{Pb}^{210}$ both accumulate in lichens, as well as $\mathrm{Cs}^{137}$ and $\mathrm{Sr}^{90}$ from nuclear explosions (2).

Besides being scarce, the various findings of different studies on the nutritional value of lichens have not been consistent. This variation probably partly arises from variation in nutrient composition between and within species. Some of the variation is also likely experimental error as some of the studies are quite old.

\section{Human use of lichens for food}

Reports that indicate significant use of lichens, primarily as food material, are gathered together and briefly reviewed. It is worth noting that even a given usage may appear to be a rather small percentage of the diet, it could yet play an important strategic role. In many instances lichens are one of the few foods available in winter, so they could be especially important during the most stressful periods for people living in the North. In other cases lichens may ensure supplementation with vital nutrients, contributing to overall diet composition.

\section{Lichens for food}

Most data about lichen usage for food are related to the Northern parts of Europe and America. The Icelandic 'Johsbok' (law book) refers to 'gros' (lichen, seems to refer to Cetraria islandica (L.) Ach.) that has been mentioned in 1280 as a natural product which could not be collected without the landowner's permission." (2). Flavocetraria nivalis (L.) Kdrnefelt \& Thell was sometimes collected for food along with Cetraria islandica (L.) Ach. (2). A method for making glucose "molasses" from Flavocetraria nivalis (L.) Kdrnefelt \& Thell and Cetraria islandica (L.) Ach. and was developed during World War II (in 1934-3) in former
Soviet Union because of beet sugar, potatoes and grain used instead for military purposes. Syrup with brown tinge and caramel flavor was prepared from Cetraria islandica (L.) Ach., and the glucose yield was $78 \%$ of dry lichen weight (24). In Scandinavia the hardened jelly of this lichen was often mixed with lemon juice, sugar, chocolate, almonds, etc. (23). In Scandinavia, Iceland, Northern Europe and Britain nd Northern Russia Cetraria islandica's lower parts were removed, soaked in ash water or lye water for several days, boiled, rinsed, dried, ground, mixed with flour, then cooked as bread, gruel, or jelly. During the 1900 s, C. islandica was used so extensively for bread that it became scarce and picking it became forbidden unless it was to be used for human consumption." (1). Cetraria ericetorum Opiz was chopped up and added to various types of soups for flavoring by the Eskimos (26).

Lobaria quercizans (Ach.) Michx. was a favorite old food of in the area of Great Lakes in North America (43). Lobaria scrobiculata (Scop.) DC. was eaten plain, right from the tree by the Eskimo in Alaska; Nephroma arcticum (L.) Torss. was eaten boiled with fish eggs in Alaska and western Canada (42). The Eskimo stored it until winter and then boiled with crushed fish eggs (26).

In North America Umbilicaria muehlenbergii (Ach.) Tuck.was cleaned, broken into small pieces and added to fish broth to make a thick soup (several handfuls of lichen to one medium-sized fish). Hot water was poured over the lichen pieces before use and discarded, boiled 5-10 minutes, thickened as it cooled. This soup was considered good nourishment for a sick person since it would not upset the stomach (20). Indigenous peoples in Canada considered Umbilicaria muhlenbergii (Ach.) Tuck. agreeable and nutritious when boiled with fish (35). Most of the Great Lakes region natives would starve without Umbilicaria $s p$. $(8,43)$. Umbilicaria spp. were emergency and famine food for Canadian indigenous people (18). Umbilicaria vellea (L.) Hoffm., was considered to be pleasanter food than the other species of this genus (35).

Native American tribes and some European travelers in boreal North America used lichens for food prepared in different ways. Various lichens on rocks or trees after being washed in ashes and water, were boiled in grease. Bryoria fremontii (Tuck.) Brodo \& D. Hawksw. was cooked in various ways - rinsed in fresh water for several hours to overnight, sometimes worked with hands, steam cooked in a covered pit with plant material (often onion) for several days, dried, then stored or roasted over fire until crumbly then boiled in water to form molasses. Although it was usually cooked as above, sometimes the lichen was eaten raw in times of famine. "After babies were weaned they were given a mixture of saskatoon berry juice and'syrup' of boiled black tree lichen" (11). "It was believed that pregnant women should not eat this lichen because it would make their babies dark" (37). Sometimes the lichen was boiled and eaten with fish, grease, or berries (18). Another lichen, used in the diet, Nephroma arcticum (L.) Torss. was collected and stored until winter, then boiled with crushed fish eggs and eaten. Cetraria ericetorum Opiz, 
Hypogymnia physodes (L.) Nyl., and Flavocetraria cucullata (Bellardi) Kdrnefelt \& Thell were chopped and boiled in soup. Umbilicaria spp. and Lasallia spp. were often boiled in several changes of water and eaten in soup or alone. Lobaria scrobiculata (Scop.) DC. was eaten raw right off tree. Lobaria amplissima (Scop.) Forssell, and other unidentified lichens on white pine were boiled until looked like scrambled eggs, then eaten; or dried, boiled, then used in broth. Lobaria amplissima (Scop.) Forss. was also made into porridge. Umbilicaria muehlenbergii (Ach.) Tuck. was added to fish broth to make a thick soup.

There were traditions to use lichens for food also in Japan Umbilicaria esculenta (Miyoshi) Minks. was eaten in soups and salads (30). The Japanese consumed several hundred kilograms annually of Umbilicaria esculenta (Miyoshi) Minks. as a delicacy in soups, or deep fried." (30). Known as "Iwa-take" meaning "rock mushroom, Umbilicaria esculenta (Miyoshi) Minks. was very difficult to collect, very expensive, used as a "dainty" in a high-class dinner (17).

In India Everniastrum cirrhata (Fr.) Hale ex Sipman after being boiled and liquid removed, was fried and eaten as a vegetable. Parmotrema chinense (Osbeck) Hale \& Ahti, Parmotrema reticulatum (Taylor) M. Choisy, and Peltigera canina (L.) Willd. were also used as food (29).

Interestingly, in France lichens were used in manufacture of chocolates and pastries, where lichenin was a filler and substituted for commercial starch (23).

In $19^{\text {th }}$ century in Egypt Pseudevernia furfuracea (L.) Zopf and Evernia prunastri (L.) Ach. imported from Greek islands were used in breadmaking (3). In Egypt and Turkey it was used also for jelly production, or fermented (35). No data about lichen usage for food in Bulgaria were found. West Central Asians and North Africans used Aspicilia esculenta (Pall.) Flagey ground, mixed with meal to one-third its weight, and made into bread, or it had been fermented with honey (40).

Additionally to being used as food for humans, Cetraria islandica (L.) Ach. was used to feed domestic animals in Sweden, mainly during World War II - for pigs (1) and cows (23). It has been reported that in the years of famine in Scandinavia "a farmer having 10 cows and some sheep and goats uses yearly 60 sledge loads of lichens for his stock.". In Harjedalen (Sweden) various lichens were collected, placed into small blocks and frozen during the winter and later used as food for cattle. It was considered that the cow's milk was more beneficial and plentiful on this diet (1). In times of food shortage in Alaska (Cook Inlet) Cetraria islandica (L.) Ach. was fed to dogs (16). The Eskimo near Bethel, Alaska used "caribou food" lichens soaked overnight with ashes from fire, rinsed, boiled with meat into thick jelly for dog food (15).

\section{Lichens as spices and delicacies}

In India Parmelia abessinica Kremp. and Parmelia physodes (L.) Nyl., were sold in the market and were used as food material and as condiment in curry. The lichens were considered to be a delicacy (9). Parmotrema nilgherrense (Nyl.) Hale was a principal component of Kabul Garam Masala, a spice mixture which was usually added at the end of cooking in India. "Shops and street sellers in the markets offered the stock "dagaful" (stone flowers), a mixture of Parmotrema tinctorum (Delise ex Nyl.) Hale, P. nilgherrense, (Parmotrema reticulatum (Taylor) M.Choisy, Parmotrema sancti-angelii (Lynge) Hale, Ramalina, and Usnea sometimes was included (29). The curry additive Kubal Garam Masala included a high proportion of various Parmeliaceae (especially Parmotremaand Everniastrum species) as well as Ramalina and Usnea. In addition, the above lichens were also sold loose and added to curry as a bulking agent with mild preservative properties. The amount of material collected for these purposes placed a heavy burden on the diminishing lichen flora of the Indian territories (30).

In Western Saudi Arabia, Kuwait, and Oman Parmotrema tinctorum (Delise ex Nyl.) Hale was used as a food spice. Flavocetraria cucullata (Bellardi) Kdrnefelt \& Thell in Alaska was used as condiment for fish or duck soup (42).

\section{Lichen tea}

Cladonia rangiferina (L.) F.H.Wigg. was used by French fur traders in Quebec as a tea when provisions were exhausted (35). N. arcticum was taken as an infusion to treat "weakness" in Alaska (42). Apart from their food value, lichens may be important as a source of free water during periods of cold and low temperatures (6), mainly to animals. Sometimes raw thallus of Bfremontii was chewed as thirst quencher (38).

\section{Use of lichens in alcohol production}

Cladonia rangiferina rangiferina (L.) F.H.Wigg. and other lichens were used to make brandy from lichen-derived alcohol. The industry was growing near Stockholm in 1883, but closed in 1884 because local lichen supplies were exhausted (34).

In Europe Lobaria pulmonaria (L.) Hoffm. was used as a substitute for hops (21). There are reports that in the India Himalayas regions Darjeeling and Sikkim the lichen was used for brewing, however this may refer to reports of European/Russian use rather than local use (5). There are data that in Russia and Siberia lichens were used instead of hops in one or more monasteries which served bitter and highly intoxicating beer to travelers (23). The beer of a certain Siberian monastery which was noted for its peculiar bitterness owed this to Lobaria pulmonaria (L.) Hoffm. (32). A method for making glucose "molasses" from Cladonia stellaris (Opiz) Pouzar \& Vizda was developed during World War II (in 1934-3) in former Soviet Union because beet sugar scarce and potatoes and grain used for military purposes. The syrup was so bitter that "better applied to the production of alcohol or as a medium for growing food yeasts" than used as syrup. Glucose yield was $75 \%$ of dry weight (24).

Lobaria pulmonaria (L.) Hoffm. was used instead of hops for making beer in Siberia, while in Northern Europe and other parts of Northern Russia Anaptychia ciliaris (L.) 
Kürb., Bryoria spp., Cetraria islandica (L.) Ach., Cladonia rangiferina (L.) F.H.Wigg. Ramalina farinacea (L.) Ach., Ramalina fastigiata (Pers.) Ach., Ramalina fraxinea (L.) Ach., and Usnea florida (L.) F.H.Wigg. were used to make brandy: the lichen was steamed under pressure for several hours, weak acid was added, steamed again, neutralized with alkali, and fermented. Molasses were made from Alectoria ochroleuca, Cetraria, and Cladionia spp. in Northern Russia: the lichens were soaked in weak alkali, hydrolyzed with dilute sulfuric acid, neutralized with chalk, and purified with activated carbon.

In Tarahumar uplands (Mexico) Usnea subfusca Stirtonwas widely used as catalyst in making fermented corn (and cornstalk) beverages (27).

\section{Tobacco substitutes}

In Mauritania Parmelia paraguariensis Lynge was used as tobacco and was imported from several hundred kilometers to the Northwest (29)

In India crude drug 'chharila', extracted from three Parmelia spp. is sold in Indian bazaars and used in Ayurvedic and Unani systems of medicine, considered to be a good cephalic snuff (31).

A novel Dictyonema $s p$. was used by the native Indians in Ecuador as a hallucinogen in shamanistic rituals (10).

\section{CONCLUSION}

The cohesion of the data from available studies of the lichen nutritional value and usage gives reason to think that lichens present a great and worth to be rediscovered potential source of functional foods. Data about the effect of lichens used for food on gene expression levels, protein and metabolite variations in humans virtually do not exist. This is a great challenge to explore the effect of lichens in food with respect to the nutrigenomics advent and compare with data about other potential sources for nutraceuticals and new food additives.

\section{REFERENCES}

1. Ahmadjian, V., S. Nilsson. Swedish lichens. Sweden Yearbook (American Swedish Historical Foundation), 1963.

2. Airaksinen M. M., P. Peura, L. Ala-FossiSalokangas, S. Antere, J. Lukkarinin, M. Saikkonen, F. Stenback. Toxicity of plant material used as emergency food during famines in Finland.- $J$. Ethnopharmacol., 18, 1986, 273-296.

3. Baumann, B.B. The botanical aspects of ancient Egyptian embalming and burial. -Econ. Bot., 14, 1960, No. 1, 84-104.

4. Behera B.C., N. Verma, A. Sonone, U. Makhija. Determination of antioxidative potential of lichen Usnea ghattensis in vitro .- LWT - Food Sci. Technol., 39, 2006, No 1, 80-85.
5. Biswas, K. Common Medicinal Plants of Darjeeling and the Sikkim Himalayas. West Bengal: Bengal Government Press, 1956.

6. Brodo I. M., S. D. Sharnoff, S. Sharnoff. Lichens of North America, Yale University Press, New Haven CT, 2001.

7. Cempirkova H., K. Vecerova. Involvement of antioxidants in photoprotection of lichens. In: Physiologia Plantarum. Special Issue: Redox Signal Integration. FESPB 2008 Abstracts, Lund, John Wiley-Blackwell, Tampere, Finland, 2008, 9-34.

8. Chamberlain, L.S. Plants used by the Indians of Eastern North America.- Am. Nat., 35, 1901, 1-10.

9. Chopra, R. N., I. C. Chopra, K. L. Handa, L. D. Kapur. Indigenous drugs of India. Academic Publishers, Calcutta \& New Delhi, 1958.

10. Davis, E. W., J. A. Yost. Novel hallucinogens from eastern Ecuador.- Bot. Mus. Leaflets, Harvard Univ.,29, 1983, No 3, 291-295.

11. Gabriel L., H. E. White. Food and medicines of the Okanakanes. (Compiled by Hester White).- Report of the Okanagan Historical Society of Vernon, British Columbia, 18, 1954, 24-29.

12. Gulcin I., M. Oktay, O.Kufreviolu, A. Aslan. Determination of antioxidant activity of lichen Cetraria islandica (L) Ach, - J. Ethnopharmacol., 79, 2002, No 3, 325-329.

13. Guo L., Q. Shi, J.-L. Fang, N. Mei, A. A. Ali, S. M. Lewis, J. E. A. Leakey, V. H. Frankos. Review of usnic acid and Usnea barbata toxicity.- J. Environ. Sci. Health, Part C, 26, 2008, No 4, 317 - 338.

14. Ivanov D., Y. Kiselova, D. Ivanova. Cetraria islandica as a natural source of antioxidants.-

"Ovidius" University Annals of Medical Science Pharmacy, 2008 (in press).

15. Jones A. Nauriat Niginaqtuat (Plants that We Eat). Anore Jones and Maniilaq Association, 1983.

16. Kari P. R. Tanaina Plantlore. US Nat. Park Service, Alaska Region, 1987.

17. Kawagoe S. The market fungi of Japan. - $B r$. Mycol. Soc. Trans., 10, 1925: 201-206.

18. Kuhnlein H. V., N. J. Turner. Traditional plant foods of Canadian indigenous peoples: Nutrition, botany and use. Taylor \& Francis, 1991.

19. Lal B. M., K. Ranganatha Rao. The food value of some Indian lichens.- J. Sci. Ind. Res., 15, 1956, No C, 71-73.

20. Leighton A. L. Wild plant use by the Woods Cree (Nihithawak) of East-Central Saskatchewan. Nat. Mus. of Can, Mercury Series, Canadian Ethnology Service paper 101, Ottawa, 1985.

21. Lindley J. Medical and Oeconomical Botany. Bradbury and Evans, London. 1849.

22. Llano, G.A.P. Lichens: their biological and economic significance.- The Bot. Review, 10, 1944, No 1, $1-65$.

23. Llano G. A. P. Economic uses of lichens.- Econ. Bot., 2, 1944, 15-45.

24. Llano G. A. P. Utilization of lichens in the arctic and subarctic. - Econ. Bot., 10, 1956, No 4, 367-392.

25. Nordfeldt S., W. Cagell, M. Nordkvist. Smaltbarhetsfiirsiik med renar Ojebyn, 1957-1960.Statens Husdjursforsok Bull., 151, 1961, 1-14. 
26. Oswalt W. H. A Western Eskimo ethnobotany. Anthropol. Papers Univ. Alaska, 6, 1957, No 1, 16-36.

27. Pennington C. W. The Tarahumar of Mexico. Univ of Utah Press, 1963.

28. Richards on D. H. S. The vanishing lichens. Newton Abbot, David and Charles, 1975.

29. Richardson D. H. S. Medicinal and other economic aspects of lichens. In: CRC Handbook of Lichenology, Vol. III., M. Galun, ed., 1988, 93-108

30. Richardson D. H. S. Lichens and man. In: Frontiers in Mycology, D. L. Hawksworth, ed., 1991, 187-210.

31. Saklani A., D. K. Upreti. Folk uses of some lichens in Sikkim.- J. Ethnopharmacol., 37, 1992, 229-233.

32. Schneider A. A text-book of general lichenology. Willard N. Clute \& Co., Binghamton, 1897.

33. Scotter G. W. Chemical composition of forage lichens from northern Saskatchewan as related to use by barren-ground caribou.- Can. J. Plant Sci., 45, 1965, 246-250.

34. Smith A. L. Lichens. Cambridge, Cambridge Univ. Press, 1921.

35. Sturtevant E. L. Sturtevant's edible plants of the world. State of New York, Department of Agriculture, J. B. Lyon Co. State Printers, Albany, 1919.

36. Swartz M. D., Nutrition investigations on the carbohydrates of lichens, algae, and related substances.Conn. Acad. Arts \& Sci. Trans., 16, 1911, 247-382.
37. Turner N. J., R. Bouchard, D. I. D. Kennedy. Ethnobotany of the Okanagan-Colville Indians of British Columbia and Washington. Occasional Papers of the British Provincial Museum, Province of British Columbia, 21, 1980.

38. Turner N. J., A. Davis. "When everything was scarce": the role of plants as famine foods in northwestern North America.- J. Ethnobiol., 13, 1993, No 2, 171-201.

39. Wang T., G. Bengtsson, I. Karnefelt, L. O. Bjorn. Provitamins and vitamins $\mathrm{D}_{2}$ and $\mathrm{D}_{3}$ in Cladina spp. over a latitudinal gradient: possible correlation with UV levels.- J. Photochem. Photobiol., B: Biology, 62, 2001, 118-122.

40. Watt J. M., M. R. Breyer-Brandwijk. The medicinal and poisonous plants of Southeastern and Eastern Africa. Edinburgh and London, E. and S. Livingstone, Ltd., 1962.

41. Weissman L., J. Garty, A. Hochman. Characterization of enzymatic antioxidants in the lichen Ramalina lacera and their response to rehydration.Appl. Environm. Microbiol., 71, 2005, No 11, 6508-6514.

42. Wils on M. R. Notes on ethnobotany in Inuktuit.Western Can. J. Anthropol., VIII, 1978. No 2-4,180-196.

43. Yarnell R. A. Aboriginal relationships between culture and plant life in the Upper Great Lakes Region. Anthropological Papers, Univ. of Michigan, 1964. 